\title{
First report of Phoma multirostrata in Australia
}

\author{
H. Golzar • V. Lanoiselet • C. Wang • Y. P. Tan • \\ R. G. Shivas
}

Received: 30 October 2014 / Accepted: 27 January 2015 /Published online: 14 February 2015

(C) Australasian Plant Pathology Society Inc. 2015

\begin{abstract}
Dark grey leaf lesions were observed on coriander (Coriandrum sativum) commercially grown at Wanneroo, Western Australia during November 2013. A species of Phoma was consistently isolated from leaf lesions. The pathogen was identified as Phoma multirostrata using morphological characteristics, DNA sequencing comparisons and pathogenicity testing. This is the first report of Phoma multirostrata causing leaf spot on coriander in Australia.
\end{abstract}

\section{Keywords Phoma $\cdot$ Leaf lesion · Coriandrum sativum}

The genus Phoma consists of a large number of endophytes, saprobes and plant pathogens, some species causing serious diseases on economically important plant species worldwide (Aveskamp et al. 2008). Phoma multirostrata, (P.N. Mathur, S.K. Menon \& Thirum.) Dorenb \& Boerema has been reported on a various hosts, including Coriandrum sativum (Hashmi and Ghaffar 1991), Ajuga multiflora (Lou and $\mathrm{Hu} 2008$ ), Dipteryx alata (Anjos et al. 2009) and Fuchsia $\times$ hybrida (Garibaldi et al. 2010).

Coriander is usually grown for its fresh leaves; however production of the spice seed for export is also significant in Australia (Hooper and Dennis 2002; Foster and Bird 2009).

In Australia, Pseudomonas syringae pv. coriandricola and Septoria sp. have been reported causing leaf lesions on coriander (Hooper and Dennis 2002) but this is the first report of P. multirostrata on coriander.

H. Golzar $(\bowtie) \cdot$ V. Lanoiselet $\cdot$ C. Wang

Department of Agriculture and Food Western Australia, Bentley

Delivery Centre, Brisbane, WA 6983, Australia

e-mail: hgolzar@agric.wa.gov.au

Y. P. Tan • R. G. Shivas

Department of Agriculture, Fisheries and Forestry, Plant Pathology

Herbarium, Biosecurity Queensland, GPO Box 267,

Brisbane, QLD 4001, Australia
Coriander samples presenting leaf lesions were randomly collected from a commercial property at Wanneroo, Western Australia during November 2013. The symptoms appeared as dark greyish irregular lesions that coalesced to form larger necrotic areas on the leaves (Fig. 1). The pycnidia of the fungus were black, embedded in the infected leaf tissues and developed on senescence lesions. Tissue was excised from the leading edge of lesions and surface-sterilised by immersion in a $1.25 \%$ aqueous solution of sodium hypochlorite for $2 \mathrm{~min}$, rinsed in sterile water and dried in a laminar flow cabinet. The pieces were then either (a) placed on potato dextrose agar (PDA) and incubated at $22 \pm 3{ }^{\circ} \mathrm{C}$ for 7 days, fungal colonies subsequently sub-cultured onto oatmeal agar (OA) and then single-spored to obtain pure cultures; or (b) to develop fungal morphological characteristics, placed in trays on moist filter paper and incubated at $25{ }^{\circ} \mathrm{C}$ with a 12 -h dark and light cycle for two weeks. After 14 days the fungal colonies were dark-olivaceous and dark-black in reverse. Conidiomata were globose to subglobose, $165-350 \mu \mathrm{m}$ in diam. Pycnidia were dark brown, solitary or congregate with inconspicuous neck (Fig. 2). Pycniospores were unicellular hyaline, guttulate, $4.5-7 \times 1.5-2.5 \mu \mathrm{m}$ (Fig. 3). Brown chlamydospores formed after three weeks on PDA. All cultural and morphological characteristics of the isolates were similar to those described for P. multirostrata (Boerema et al. 2004).

A culture of $P$. multirostrata was deposited in the Western Australia Plant Pathogen Collection (WAC13683).

Two representative isolates morphologically identified as P. multirostrata were grown on PDA for two weeks at $25^{\circ} \mathrm{C}$. DNA was extracted from fungal mycelium with the DNeasy Plant mini Kit (Qiagen, Melbourne, Vic., Australia) according to the manufacturer's instructions. The rDNA internal transcribed spacer (ITS) region was amplified with primers ITS1 and ITS4 (White et al. 1990), Actin gene (ACT) amplified with primers ACT-512 $\mathrm{F}$ and ACT-783R and the translation elongation factor $1-\alpha(E F-1 \alpha)$ was amplified with primers 


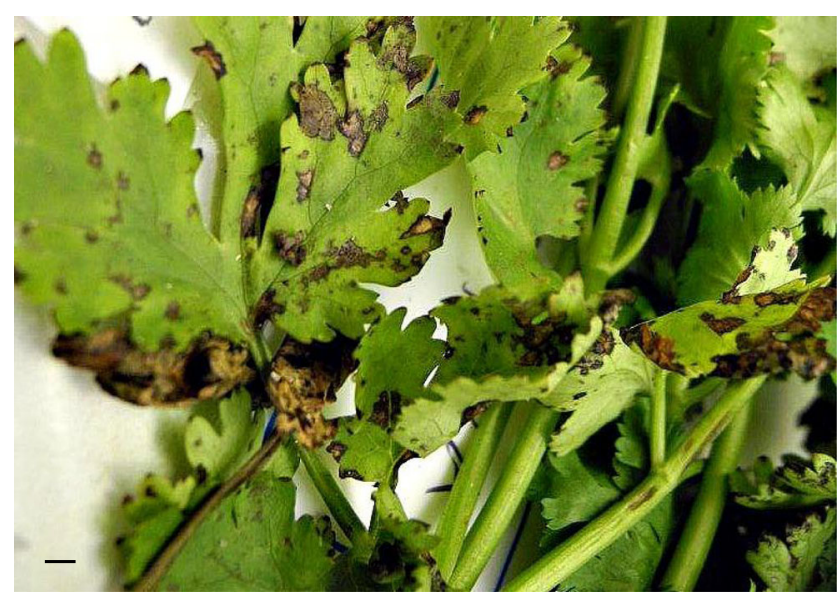

Fig. 1 Leaf lesions on coriander (Coriandrum sativum) caused by Phoma multirostrata. Bars $=5 \mathrm{~mm}$

EF1-728 F and EF1-986R (Carbone and Kohn 1999). The relevant sequence information for a representative isolate was submitted to GenBank as Accession Numbers KM659039, KM891729 and KM891728 for the ITS, Actin and EF- $1 \alpha$ regions, respectively. BLAST results for the ITS, ACT, EF- $1 \alpha$ sequence indicated 100 and $99 \%$ identity with nucleotide sequences for $P$. multirostrata (Accession No KJ767077, KJ426920, KJ427146, respectively).

A pathogenicity test was carried out on three weeks old coriander seedlings in a randomised trial with four replications inside a glasshouse. The two representative $P$. multirostrata isolates (21-d-old cultures) were used for inoculation and plants were separately sprayed to run-off with a conidial suspension $\left(10^{6}\right.$ spores $\left./ \mathrm{mL}\right)$ of each isolate. The control plants were sprayed with sterile distilled water. Inoculated plants were placed in a humidifier for $48 \mathrm{~h}$ then transferred to a growth-room at $22{ }^{\circ} \mathrm{C}$ and a $12-\mathrm{h}$ dark and light cycle. Two weeks post inoculation disease symptoms were identical to those on naturally infected plants. Control plants remained

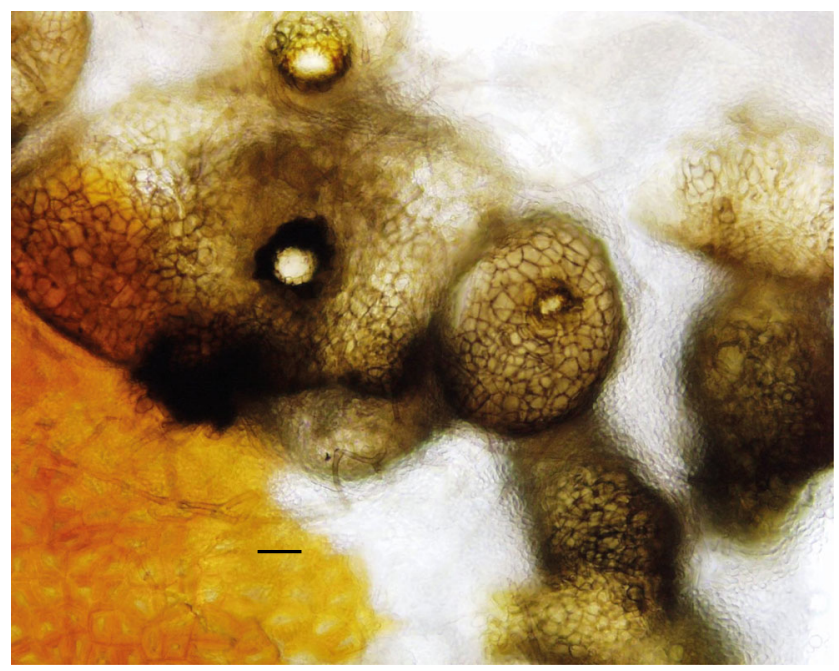

Fig. 2 Phoma multirostrata, pycnidia . Bars $=40 \mu \mathrm{m}$



Fig. 3 Phoma multirostrata, pycniospores. Bars $=10 \mu \mathrm{m}$

asymptomatic. Koch's postulates were fulfilled by reisolating the pathogen from the symptomatic tissue. The identity of the pathogen was confirmed as P. multirostrata using morphologal and DNA sequence analysis. . To the best of our knowledge, this is the first report of $P$. multirostrata causing leaf spot on coriander in Australia.

Acknowledgments The authors would like to thank Ms Annette Bwye and Ms Mirjana Banovic for technical assistance.

\section{References}

Aveskamp MM, de Gruyter J, Crous PW (2008) Biology and recent developments in the systematics of Phoma, a complex genus of major quarantine significance. Fungal Divers 31:1-18

Boerema GH, Gruyter J de, Noordeloos ME, Hamers MEC (2004) Phoma Identification Manual: Differentiation of Specific and Infra-specific Taxa in Culture. CABI Publishing

Carbone I, Kohn LM (1999) A method for designing primer sets for speciation studies in filamentous ascomycetes. Mycologia 91:553556

dos Anjos JRN, Charchar MJD, dos Anjos SSN, Junqueira NTV, Silva MS (2009) Leaf spot in Baru (Dipteryx alata) caused by Phoma multirostrata. Rev Bras Frutic 31:593-595

Foster M, Bird J (2009) World imports and import prices in National Research, Development and Extension Strategy for New and Emerging Industries, page 114-116. Available online at https:// rirdc.infoservices.com.au/downloads/09-138

Garibaldi A, Gilardi G, Gullino ML (2010) First report of leaf spot caused by Phoma multirostrata on Fuchsia $\times$ hybrida in Italy. Plant Dis 94: 382

Hashmi MH, Ghaffar A (1991) Phoma multirostrata on coriander in Pakestan. Pak J Bot 23:127-130

Hooper P, Dennis J (2002) Coriander- overcoming production limitations. Available online at https://rirdc.infoservices.com.au/downloads/02147

Lou BG, Hu XQ (2008) First report of blackleg of Ajuga multiflora caused by Phoma multirostrata in China. Plant Dis 92:981

White TJ, Bruns T, Lee S, Taylor J (1990) Amplification and direct sequencing of fungal ribosomal RNA genes for phylogenetics. In: Innis MA, Gelfan DH, Sninsky JJ, White TJ (eds) PCR protocols: a guide to methods and applications. Academic, San Diego, pp 315322 